\title{
Symptom self-management strategies reported by adolescents and young adults with cancer receiving chemotherapy
}

\author{
Lauri A. Linder ${ }^{1}$ - Jeanne M. Erickson ${ }^{2}$ - Kristin Stegenga ${ }^{3}$. \\ Catherine Fiona Macpherson $^{4} \cdot$ Sarah Wawrzynski $^{5} \cdot$ Christina Wilson $^{6}$. \\ Suzanne Ameringer ${ }^{7}$
}

Received: 12 April 2017 / Accepted: 27 June 2017 / Published online: 17 July 2017

(C) Springer-Verlag GmbH Germany 2017

\begin{abstract}
Purpose Adolescents and young adults (AYAs) with cancer experience multiple symptoms related to their cancer and its treatment which can negatively impact their development and quality of life. An understanding of the strategies AYAs use to self-manage their symptoms is limited. This study described symptom self-management strategies reported by AYAs with cancer using an iPad-based symptom heuristics tool, the Computerized Symptom Capture Tool.

Methods The study used a cross-sectional, descriptive design. AYAs' free text responses relating their symptom selfmanagement strategies were explored using qualitative content analysis procedures. Strategies were examined overall and by individual symptoms.

Results Seventy-two AYAs 13-29 years of age (mean 18.4 years) reported a total of 772 symptom selfmanagement codes for 585 individual symptoms. These codes were organized into 119 distinct categories. These categories
\end{abstract}

Lauri A. Linder

lauri.linder@nurs.utah.edu

1 College of Nursing, University of Utah and Cancer Transplant Center, Primary Children's Hospital, Salt Lake City, UT, USA

2 College of Nursing, University of Wisconsin-Milwaukee, Milwaukee, WI, USA

3 Children's Mercy Hospital, Kansas City, MO, USA

4 Seattle Children's Hospital, Seattle, WA, USA

5 College of Nursing, University of Utah and Pediatric Critical Care Services, Primary Children's Hospital, Salt Lake City, UT, USA

6 Virginia Commonwealth University, Richmond, VA, USA

7 College of Nursing, Virginia Commonwealth University, Richmond, VA, USA were further organized into 16 subthemes and 3 overarching themes: "Things I Take $\ldots$ or Not" ( $n=209$ codes), "Physical Care Things I Do" ( $n=367$ codes), and "Psychosocial Care Things I Do" ( $n=132$ codes). AYAs frequently reported strategies from all three of the symptom self-management themes to manage individual symptoms; however, "medications" was the most frequently reported strategy.

Conclusion AYAs receiving chemotherapy use multiple common, yet uniquely individual symptom self-management strategies. AYAs' reported strategies range from those that involve shared management with a healthcare provider to those that AYAs implement independently. The study provides a foundation for future research to empower AYAs to engage in symptom self-management and to guide healthcare providers as they discuss developmentally relevant and evidence-based symptom self-management strategies.

Keywords Self-management · Symptoms · Adolescent and young adult cancer $\cdot$ Heuristics $\cdot$ Technology $\cdot$ Chemotherapy

\section{Introduction}

Adolescents and young adults (AYAs) with cancer (age 1539 years) are an underserved and understudied population [1]. Along with rising cancer incidence in this age group, this disparity has led to an increased interest in their unique needs. Independence, school, partner, family, and career choices are just a few of the milestones that occur during this developmental stage $[2,3]$. Cancer can disrupt these developmental tasks - necessitating dependence where independence was emerging, putting school and career goals on hold, dictating treatments that challenge intimacy and fertility - resulting in short and long-term effects. An optimal approach to AYA cancer care must consider these developmental concerns. 
Multiple symptoms, sometimes unrelated and sometimes clustered together, due to cancer and its treatment can negatively impact AYAs' development and quality of life [4, 5]. Common symptoms, such as nausea, fatigue, and hair loss, are expected by both patients and healthcare providers, and are almost universally associated with cancer treatment. Other distressing symptoms include drowsiness, lack of appetite, difficulty sleeping, and irritability [6]. While chemotherapy is the most common named cause of their symptoms, AYAs have multiple other explanations for their symptoms. For example, lack of appetite can be caused by undesirable food and nausea in addition to chemotherapy, difficulty sleeping can be caused by disruptions from staff in the hospital as well as medications, such as steroids, and irritability can be caused by fatigue [6].

AYAs are tasked with learning how to live with cancer and become active participants in managing their own care. Selfmanagement is the dynamic process by which individuals integrate strategies to cope with their disease and disease- or treatment-related symptoms in the context of their daily lives. This process also includes acquiring knowledge about the disease and treatment and developing skills to self-monitor and abilities to make decisions and take appropriate action [7]. Effective self-management strategies can improve shortand long-term outcomes related to physical and emotional distress and quality of life and reduce health care costs.

Most young people with cancer have the desire to learn about self-management options and skills [8,9]. Many desire to be part of the treatment process and value an alliance with their providers [10-12], although they may differ in their attitudes and preferences toward autonomy, information seeking, and communication with providers [12]. Self-management needs include knowledge about their cancer and treatment, practical skills to manage side effects and procedures, guidance about navigating the health care system, and support specific to AYAs [13]; however, their needs are frequently unmet, especially related to information about their cancer, infertility, diet, and nutrition, which contributes to distress $[14,15]$. Males, younger patients, and those diagnosed with a central nervous system (CNS) cancer may demonstrate poorer selfmanagement skills [16]. An understanding of the actual strategies used by AYAs with cancer to self-manage their symptoms is limited. Gaining insight into their specific self-management strategies will help researchers create and deliver effective clinical interventions to optimize self-management skills.

Mobile technology and Web-based platforms offer new strategies to deliver information about self-management of common symptoms, such as pain [17] and eating problems [18], and are feasible and acceptable to these young patients. An investigator-developed iPad application (app), the Computerized Symptom Capture Tool (C-SCAT) uses a heuristics approach to explore symptoms and symptom clusters from the perspective of the individual [19]. The C-SCAT also elicits free text responses regarding AYAs' experiences, including their own symptom self-management strategies. This paper describes symptom self-management strategies reported by AYAs with cancer receiving chemotherapy using the CSCAT.

\section{Methods}

\section{Design}

This cross-sectional, descriptive study explored AYAs' symptom self-management strategies using qualitative content analysis procedures. Gender and age-related differences between self-management strategies reported by adolescents (1317 year olds) and young adults (18-29 year olds) were also explored.

\section{Sample and setting}

Sample Eligible participants were 13 to 29 years old and receiving myelosuppressive chemotherapy for a primary diagnosis of cancer or relapsed disease in inpatient or ambulatory settings. Inclusion criteria were the receipt of at least one previous cycle of myelosuppressive chemotherapy; the ability to read, write, and speak English; and the physical and cognitive ability to complete the C-SCAT within 24-96 hours of initiating the current cycle of myelosuppressive chemotherapy.

Setting Study sites were five academic medical centers in the USA that provide treatment to AYAs with cancer. Regional representation included the Pacific Northwest, Intermountain West, Midwest, and the Southeast.

Ethical considerations Institutional review board approval was granted at each institution prior to initiating data collection. Research team members at each site conducted regular reviews of patients scheduled for inpatient admission and ambulatory clinic visits to screen for eligibility. Eligible participants were approached by an oncology team member to elicit interest in the study. A research team member met with interested participants to explain the study procedures. Written assent and parent permission were obtained from participants 13 to 17 years of age. Written informed consent was obtained from participants 18 years and older.

\section{Study measures}

Demographic and clinical data Demographic and clinical data were obtained from participants' medical records.

C-SCAT The study measure was the Computerized Symptom Capture Tool (C-SCAT), an investigator-developed iPad- 
based app [19]. The C-SCAT uses a heuristics approach to symptom and symptom cluster assessment and includes the 30 symptoms of the Memorial Symptom Assessment Scale (MSAS) 10-18 [20].

The C-SCAT guides users through a series of screens that allows them to create a graphical image of their symptom and symptom cluster experience during the prior 24 hours (Fig. 1). Users select symptoms they have experienced. For each selected symptom, they are asked a series of free text questions addressing perceived symptom causes, alleviating and exacerbating factors, and the effect of that symptom on their dayto-day lives. Users can create lines between symptoms they feel are connected and add arrows to indicate causal relationships between symptoms. Users are asked to identify groups or clusters of symptoms that they perceive to be related to one another. They are also asked to provide a name for each group and to identify the priority symptom within each group.

\section{Procedure}

Participants completed the C-SCAT either in the inpatient unit or the ambulatory clinic 24 to 96 hours following receipt of the initial dose of chemotherapy associated with a new cycle of myelosuppressive chemotherapy. A research team member was present during data collection to respond to participant questions and technical difficulties.

\section{Data management}

Data generated through the C-SCAT were encrypted and transmitted wirelessly to a password-protected Amazon $\mathrm{S}^{3}$ account [21]. Individual participants' files included screenshot images of each portion of the C-SCAT app as well as an .xml file including free text responses to the questions within the app. A larger, combined Excel file including individual symptom names along with AYAs' responses to the questions, "What do you think helps make it better?" "What do you do to make it better?" and "What do you think causes it?" was generated from the .xml files to support content analysis procedures.

\section{Analysis procedures}

Data were analyzed using descriptive statistics and qualitative content analysis. Descriptive statistics characterized the study sample as well as frequencies of responses. Qualitative content analysis strategies supported the organization of the AYAs' reported self-management strategies into categories with similar themes $[22,23]$. Each response to the questions "What do you think makes it better?" and "What do you do to make it better" was treated as a unit of analysis. Both questions were used because answers to both questions included self-management strategies. Responses to the question "What
Fig. 1 Example image of a user's symptom and symptom cluster experience

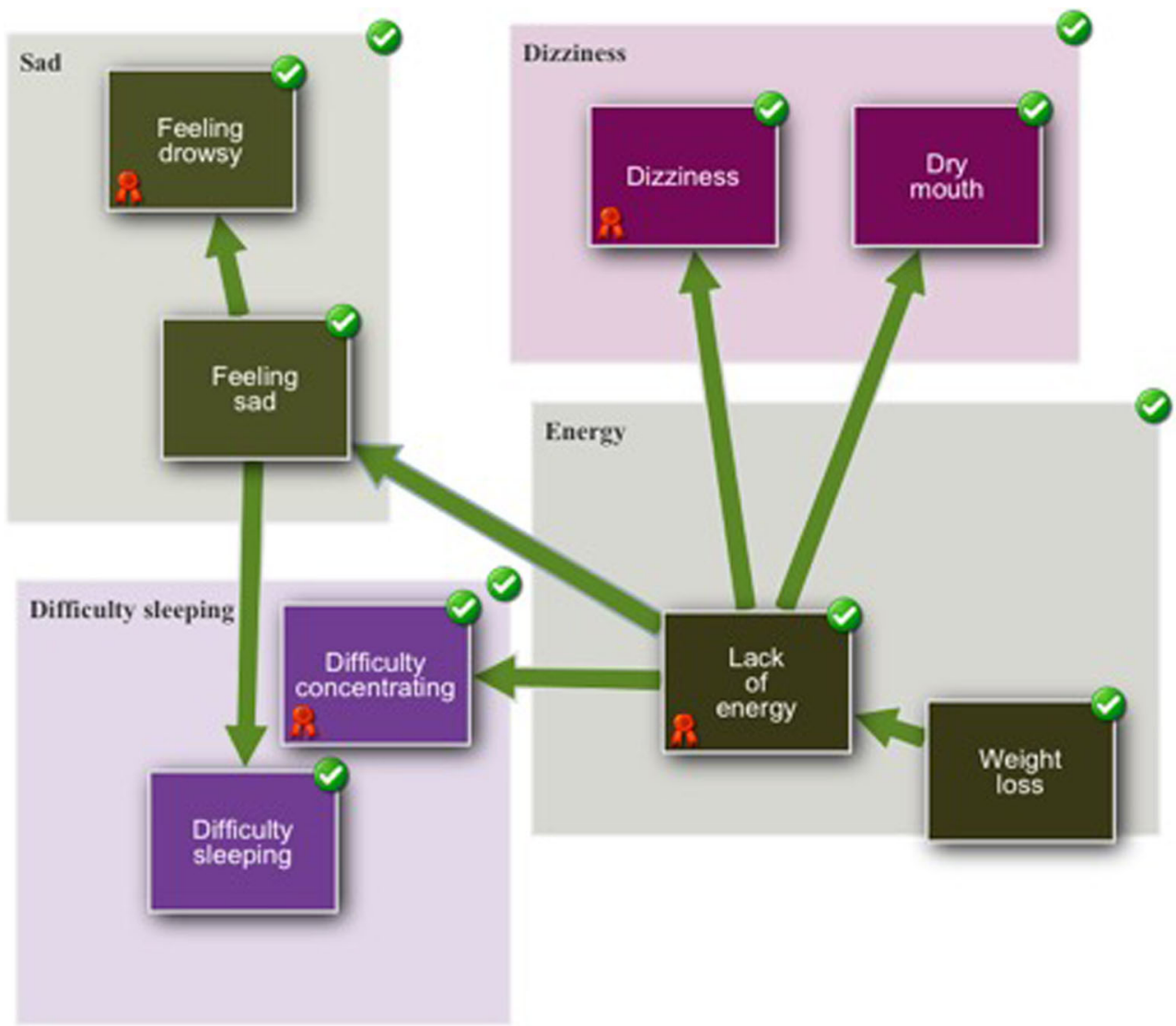


do you do to make it better?" were examined for redundancy in relation to the first question. Only responses that reflected new and distinct strategies were included in the analyses.

Two authors from separate institutions worked independently to assign one or more codes for each response. The authors met together to review responses and discuss discrepancies with two additional authors. Responses were brought to the entire author group to review and confirm consensus during scheduled team meetings. During the coding process, responses to the question "What do you think causes it?" were reviewed to gain perspective in interpreting the stated selfmanagement strategies. The authors used a constant comparative approach to review codes across individual symptoms and make refinements as needed. The codes were further grouped into categories expressing similar content. Categories were organized into subthemes, and lastly, subthemes were organized into themes.

\section{Results}

\section{Participant characteristics}

Participant characteristics are summarized in Table 1 . The study sample included 33 adolescents (13-17 years of age) and 39 young adults (18-29 years of age). Participants were a mean of 18.4 years of age ( $\mathrm{SD}=4.3), 57 \%$ were male, and 79\% were White/non-Hispanic. Diagnostic groups were representative of cancers common among AYAs with lymphoma $(30.5 \%)$ and sarcoma (29.2\%) most frequently reported.

Table 1 Participant characteristics

\begin{tabular}{lcc}
\hline & Number & Percent \\
\hline Gender & 41 & \\
Male & 31 & 57 \\
Female & & 43 \\
Age group & 33 & \\
$\quad$ Adolescent & 39 & 46 \\
Young adult & & 54 \\
Race/ethnicity & 57 & \\
White/non-Hispanic & 7 & 79 \\
Black/African-American & 4 & 6 \\
Hispanic & 3 & 4 \\
Asian/Pacific Islander & 1 & 1 \\
Other & & 30.5 \\
Diagnostic group & 22 & 29 \\
Lymphoma & 21 & 21 \\
Sarcoma & 15 & 19.5 \\
Leukemia & 14 & \\
Other solid tumor & &
\end{tabular}

Participants were a median of 3 months from their initial cancer diagnosis (range 1-156 months).

\section{Frequencies of symptom self-management strategies}

Participants reported a total of 585 individual symptoms. They provided 484 responses to the question "What do you do think helps make it better?" and 417 responses to the question "What do you do to make it better?" Of the 417 responses to the second question, 147 reflected new and distinct responses resulting in a total of 631 responses that were included in the analyses.

Data were examined to identify potential sources of missing data. Four participants (two adolescents and two young adults) experienced technical failures resulting in the loss of all free text responses for 40 symptoms. An additional 29 participants ( 23 adolescents and 6 young adults) did not provide responses to one or both of questions for each identified symptom. Of note, participants had been instructed that they had a choice about whether to provide a response for each question within the C-SCAT.

Participants reported a mean of 8 ( $\mathrm{SD}=4$; median 8 ; range 1-21) individual symptoms and a mean of 11 symptom selfmanagement strategies ( $\mathrm{SD}=7$; median 10 ; range $1-30$ ). The number of symptoms did not differ based on gender or age group. The number of self-management strategies did not differ by gender $(t=-0.36 ; p=0.72)$. Young adults, however, reported more symptom self-management strategies $($ mean $=13)$ compared with adolescents $($ mean $=9)$ $(t=-2.23 ; p=0.029)$.

\section{Themes, subthemes, and categories of symptom self-management strategies}

Strategies were examined overall (Table 2) and by individual symptoms (Table 3). Participants' responses resulted in a total of 772 symptom self-management strategy codes (individual responses), reflecting 119 distinct categories. These categories were organized into 16 subthemes, which were then organized into 3 overarching themes: "Things I Take $\ldots$ or Not" $(n=209$ codes), "Physical Care Things I Do" ( $n=367$ codes), and "Psychosocial Care Things I Do" ( $n=132$ codes). Two categories, "nothing $(n=35)$ " and "do not know $(n=29)$ " could not be abstracted past the category level. Table 2 summarizes strategies across all symptoms by categories, subthemes, and themes along with the frequency with which each category was reported.

"Things I Take ... or Not," included both prescribed and over-the-counter medications. It also included other prescribed interventions such as blood transfusions and feeding tubes as well as substances such as marijuana and caffeine. The most commonly reported types of medications were antiemetics, analgesics, and stool softeners/laxatives. 
Table 2 Symptom selfmanagement strategy themes, subthemes, and categories, with selected exemplars
Theme: Things I take $\ldots$ or not (4 subthemes and 29 categories)

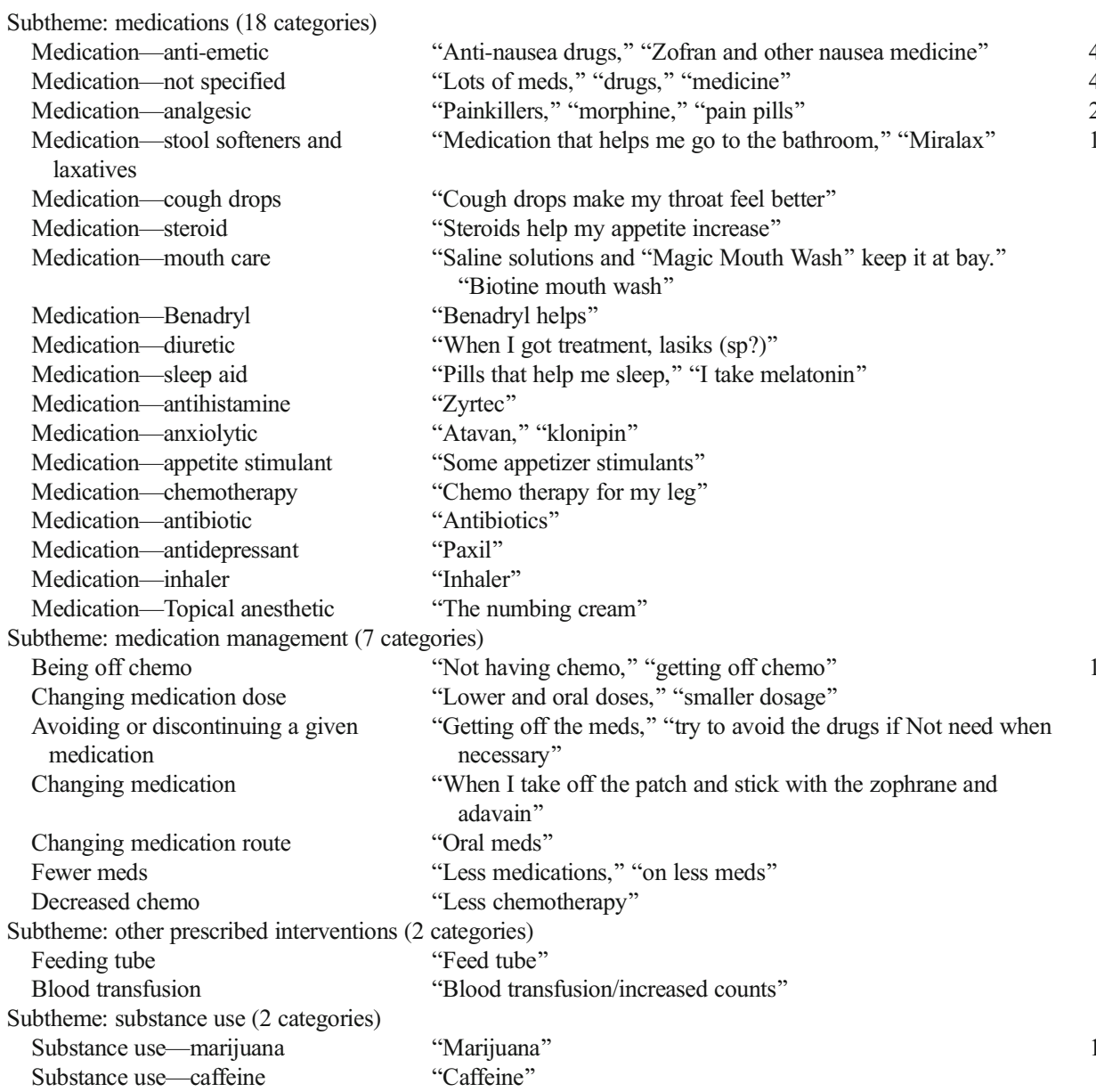

Theme: Physical care things i do (8 subthemes and 56 categories)

Subtheme: sleep/rest strategies (6 categories)

Sleep

"Sleeping," "sleeping during the day," "sleeping it off," "getting enough sleep"

Rest

"Lots of rest," "just resting"

"Just relaxing," "lots of relaxation"

Relaxing

Lying down

Naps

"When I lay down," "lying down"

"Taking naps," "naps"

"Wearing a eyeshade patch to keep it dark," "going to bed early"

Subtheme: physical activity/exercise (11 categories)

Physical activity

"Staying as much active as possible," "moving around"

Exercise

Conserve energy/reduce activity

Getting up slowly

Sitting

Maintaining a comfortable position

"Trying to do small amounts of exercises," "exercise"

"Not doing a lot of stuff like movies or games"

"Getting up slower," "standing up slowly"

"Sitting," "sitting down"

"Lying with my hands at my sides or in amy (sic) position that allows blood flow"

Avoiding specific activities

"Staying off my feet and not writing," "not forcing myself to read something when I cannot focus"

Engaging in a specific activity

Exhaustion during the day

Physical assistance

Self-awareness

Subtheme: eating strategies (12 categories)

Eating specific foods

Eating "good" food

"Also playing the ukulele And writing."

"Exhaustion during day"

"Asked for help when standing up"

"I try to listen to my body and follow what it says to do"

"Eating the food you like." "sweet or spicy foods," Just finding what type of food works well with certain drugs"

"Eating right," "trying good foods," "eating energizing foods such as fruits and vegetables"

Eating 
Table 2 (continued)
Theme: Things I take ... or not (4 subthemes and 29 categories)

\begin{tabular}{|c|c|}
\hline Eating - increasing quantity & $\begin{array}{l}\text { "Getting in more calories then I was before," "Trying to eat as } \\
\text { much as possible" }\end{array}$ \\
\hline Avoiding specific foods & $\begin{array}{l}\text { "Not eating the food that tastes funny," "Not eating a lot of salt," } \\
\text { "no cheese" }\end{array}$ \\
\hline Eating slowly & "Eating slower" \\
\hline Eating what/when I want & "Eating when I want to eat and what I want to eat" \\
\hline Trying to eat & "Eating enough food when taking meds that require it" \\
\hline $\begin{array}{l}\text { Eating and drinking just enough to } \\
\text { attempt to relieve/avoid the symptom }\end{array}$ & "Trying to maintain food and water in my stomach" \\
\hline Eating-reduced quantity & "Stop eating" \\
\hline Not being forced to eat & "Not forcing myself to eat if I can't" \\
\hline Plastic utensils & "Eating with a plastic fork" \\
\hline \multicolumn{2}{|c|}{ Subtheme: drinking/hydration strategies (3 categories) } \\
\hline Oral hydration & "Drink a lot of water," "Drinking more liquid." \\
\hline Consuming specific drinks/beverages & "Soda," "fruity drinks," "warm tea" \\
\hline Hydration & "Getting more hydrated," "plenty of fluids" \\
\hline \multicolumn{2}{|c|}{ Subtheme: appearance/personal care ( 5 categories) } \\
\hline Head/hair accessories & "Wearing a hat," "Wear fun scarfs, hats, wigs" \\
\hline Shower/bath & "Warm bath," "showering" \\
\hline Haircut/hair care & "I cut it down and then shaved it" \\
\hline Clothing & "Finding clothes that hide my skinny figure" \\
\hline Make up & "Trying to do makeup, nails" \\
\hline \multicolumn{2}{|c|}{ Subtheme: supportive care resources ( 2 categories) } \\
\hline Lotions and creams & "Lotion," "Anti itch cream" \\
\hline Mouth products and practices & "Suction," "Swabbing mouth," "Wearing chap stick" \\
\hline \multicolumn{2}{|c|}{ Subtheme: managing the physical environment ( 6 categories) } \\
\hline Decreased blankets/clothing & $\begin{array}{l}\text { "No blankets," "Not wearing the bundles of clothes people } \\
\text { usually wear for the winter time" }\end{array}$ \\
\hline Cool air/temperature & "Cooler temperatures will help," "The right temp." \\
\hline Fewer hospital-related disruptions & "Not being woken up constantly," "Less nighttime nurse visits" \\
\hline Avoid cold & "Staying away from cold items" \\
\hline Managing body temperature & "Controling body temperature" \\
\hline Moving air & "Sleeping naked under a fan" \\
\hline \multicolumn{2}{|c|}{ Subtheme: Complementary/integrative medicine strategies (11 categories) } \\
\hline Breathing & "Deep breaths," "slow breaths," "breathing" \\
\hline Warmth strategies & "Laying under my heated blanket." "Staying cozy, warm" \\
\hline Massage/back rub & "Rubbing feet," "back rubs" \\
\hline Aromatherapy & "Aromatherapy" \\
\hline Ginger & "Root ginger" \\
\hline Dietary supplement & "I have taken supplements" \\
\hline Fragranced wraps & "Lavender wraps" \\
\hline Meditation & "Meditating" " \\
\hline Peppermint & "Peppermint" \\
\hline Yoga & "Yoga" \\
\hline Cold strategies & “Cold packs" \\
\hline \multicolumn{2}{|c|}{ Theme: Psychosocial care things i do (4 subthemes and 32 categories) } \\
\hline \multicolumn{2}{|c|}{ Subtheme: psychosocial/relational strategies (11 categories) } \\
\hline Time with family & "Being around family," "seeing family" \\
\hline Talking to someone & "Talking about it," "talking to someone" \\
\hline Time with friends & "Friends," "Just having fun and enjoying time with friends." \\
\hline Quiet and/or time alone & $\begin{array}{l}\text { "Spending some time in peace and quiet," "Having a little alone } \\
\text { time" }\end{array}$ \\
\hline Time with others & "Having company," "hanging with people" \\
\hline Being at home & "Leaving and getting back home," "going home" \\
\hline Having support & "Having support," "support" \\
\hline Getting out & "Going out to places" \\
\hline Talking to family & "Talking to my mom" \\
\hline Talking to friends & "Talking to friends" \\
\hline Time with pets & "Laying on the couch with my dogs \\
\hline \multicolumn{2}{|c|}{ Subtheme: cognitive/emotional/spiritual strategies ( 5 categories) } \\
\hline Distraction & $\begin{array}{l}\text { "Doing simple fun tasks to distract me," "Having something fun } \\
\text { to focus on" }\end{array}$ \\
\hline Calm down & "Calm down and watch TV" \\
\hline Cognitive activity & $\begin{array}{l}\text { "Stimulating my brain with games or riddles or something to that } \\
\text { effect" }\end{array}$ \\
\hline Crying & "A good cry helps sometimes" \\
\hline
\end{tabular}


Table 2 (continued)

\begin{tabular}{|c|c|c|}
\hline \multicolumn{3}{|c|}{ Theme: Things I take ... or not (4 subthemes and 29 categories) } \\
\hline Praying & "Praying" & 1 \\
\hline \multicolumn{3}{|c|}{ Subtheme: living day-to-day with cancer ( 13 categories) } \\
\hline Being positive & "Being positive," "just staying positive through everything." & 7 \\
\hline Not thinking about it & "Just not think about it to much" & 7 \\
\hline Emesis & "Just barfing," "actually vomiting" & 5 \\
\hline Experiencing relief of a given symptom & $\begin{array}{l}\text { "Not having nausea or puking." "When my fever goes down or is } \\
\text { gone" }\end{array}$ & 4 \\
\hline Information & "Getting questions answered," "getting information" & 4 \\
\hline Positive future perspective & $\begin{array}{l}\text { "Thinking about making it to remission," } \\
\text { "After chemo it'll grow" }\end{array}$ & 3 \\
\hline Progressing through treatment & "Treatment and progress," "Getting it over with" & 3 \\
\hline $\begin{array}{l}\text { Attempting to avoid a behavior } \\
\text { contributing to a symptom }\end{array}$ & $\begin{array}{l}\text { "I can try to get rid of the habit of opening my mouth when I } \\
\text { sleep" }\end{array}$ & 2 \\
\hline Telling the provider & "I told the nurse and she told the doctor" & 2 \\
\hline Maintaining normalcy & "Trying to stay normal, doing normal activities" & 1 \\
\hline Maintaining usual routines & $\begin{array}{l}\text { "Overeating but, I can't overeat I have to stay healthy and } \\
\text { continue my routines" }\end{array}$ & 1 \\
\hline Managing schedule & $\begin{array}{l}\text { "Having earlier appointments, and other activities to do } \\
\text { throughout the day." }\end{array}$ & 1 \\
\hline Procedural familiarity & "the more I get it done" & 1 \\
\hline \multicolumn{3}{|c|}{ Subtheme: waiting strategies ( 3 categories) } \\
\hline Leave it alone/wait it out/time & "Let it be," "Time waiting it out" & 17 \\
\hline Not having cancer & "Not having cancer" & 1 \\
\hline Wish for symptom resolution & "Wish my hair to grow back" & 1 \\
\hline
\end{tabular}

"Medications" was reported as a strategy for 21 different symptoms including physical symptoms such as nausea, pain, vomiting, constipation, and difficulty sleeping and psychosocial symptoms such as feeling irritable, feeling nervous, and worrying. This theme also included individual strategies AYAs used with these medications such as taking a lower dose of a medication, opting for an oral versus intravenous dose, or electing not to take a given medication to self-manage specific symptoms.

"Physical Care Things I Do" strategies reflected physical care-directed efforts AYAs undertook to relieve symptoms. The most frequently reported subthemes included sleep/rest, eating, and physical activity/exercise strategies. The most frequent sleep/rest strategies included sleeping, resting, and relaxing. Eating strategies included both efforts to improve nutritional intake such as eating "good" food and increasing the quantity of food consumed. Eating strategies also involved both selecting and avoiding specific foods. Physical activity/ exercise strategies included both efforts to increase activity as well as efforts to conserve energy.

Some symptoms had common groupings reflecting common self-management strategies. For example, strategies for managing feeling drowsy, lack of energy, dizziness, and difficulty sleeping all included a continuum of efforts ranging from increasing sleep and rest to engaging in physical activity and exercise.

"Psychosocial Care Things I Do" strategies were more individualized relative to the other two themes with fewer AYAs reporting any specific strategy. Of four subthemes identified, strategies within the subthemes of "psychosocial/relational strategies" and "living day-today with cancer" were reported most frequently. "Psychosocial/relational strategies" reflected the importance of other individuals, including both family and friends, providing support to the AYA through their presence and availability to talk. In contrast, however, four AYAs related the importance of having time alone.

"Living Day-to-Day with Cancer" strategies addressed the AYA's mindset, such as being positive and maintaining a positive future perspective. For other AYAs, "not thinking about it" was perceived as a helpful symptom self-management strategy. Other psychosocial-focused symptom selfmanagement strategies frequently reported included having a "distraction" and "waiting it out."

Gender-based differences were present among the subthemes of symptom self-management strategies $\left(\chi^{2}=40.93 ; p<.001\right)$. Females more frequently reported using "complementary/integrative medicine" strategies (adjusted standardized residual $=3.8$ ), whereas males more frequently reported "substance use" strategies (adjusted standardized residual $=3.6$ ). Age-based differences in the frequencies of categories of symptom self-management strategies were also present $\left(\chi^{2}=32.47 ; p=.006\right)$. Adolescents reported "drinking/hydration strategies" more frequently (adjusted standardized residual $=2.4$ ) whereas, young adults more frequently reported substance use (adjusted standardized residual $=2.6$ ) and "managing the physical environment" (adjusted standardized residual $=2.1$ ) as symptom self-management strategies. 
Symptom self-management strategies based on individual symptoms

Table 3 summarizes the frequency with which themes and subthemes of symptom self-management strategies were reported for each symptom included within the C-SCAT. Participants reported strategies from all 3 of the symptom self-management themes for 19 symptoms. For example, AYAs reported using medications, eating strategies, and psychosocial/relational strategies to self-manage nausea. Twenty-four symptoms included strategies from at least two of the three symptom self-management themes.

\section{Discussion}

Adolescents and young adults receiving chemotherapy use multiple common, yet uniquely individual strategies to selfmanage their symptoms. Symptom self-management strategy themes reflected a continuum ranging from a more prescribed approach often requiring a shared management with the healthcare team (Things I Take ... or Not), to more highly personalized and independent self-management (Psychosocial Care Things I Do). These responses indicated that AYAs used strategies across all three themes to alleviate both physical and psychological symptoms. This illuminates the diverse approaches they take to manage symptoms, recognizing the need for shared roles as well as autonomous options. Reviewing perceived causes of individual symptoms was essential to provide a context to interpret the meaning behind the stated strategy. Although most strategies reflected more immediate actions participants were using, some strategies reflected a longer range perspective, such as "being off chemo."

The use of medications to ameliorate multiple symptoms was the predominant self-management strategy. AYAs used prescription and over-the-counter medications and also adjusted or revised the route and/or dose of medications for optimal symptom relief. Sometimes, the strategy was the choice not to take a medication in order to prevent or manage a symptom associated with that medication. For providers, teaching about safe, appropriate, and effective use of multiple medications, therefore, emerges as a priority of care, especially for these young patients who may be novices at self-managing a health condition. In addition, given the costs, potential side effects, and safety risks of "polypharmacy" regimens, providers should also explore whether non-pharmacologic alternatives to medications are available rather than choosing a medication as the first and only option for symptom relief.

The use of physical care strategies related to physical activity, sleep, rest, eating, and drinking were common and likely reflect previous lifestyle habits as well as individual preferences and coping behaviors. The necessity of adequate sleep and physical activity during cancer treatment cannot be overemphasized for overall well-being, recovery, and control of symptoms. To relieve gastrointestinal symptoms, AYAs named a diversity of eating and drinking strategies, which are largely under their own control. The appropriateness of their chosen strategies, such as "not eating at all" or "avoiding certain foods" or "drinking lots of fluids," and effects on their overall nutritional status and fluid balance, however, are unknown.

The participants' endorsement of multiple, diverse psychosocial approaches to relieve symptoms is indicative of the varied preferences and options available for symptom management. Peer and family support are known to be important parts of the psychosocial support picture for AYAs [24].

The responses, "nothing" $(n=35)$ and "do not know" ( $n=29)$ warrant further study. Participants took the initiative to answer with these specific phrases rather than simply not responding, which suggests the need to explore what they mean. Do these answers suggest that AYAs have no idea how to manage the symptom or that they have tried strategies that have not worked? Understanding these responses within the context of the AYA's symptom management experience will provide valuable information about how they perceive challenges to symptom self-management.

The distinctive developmental characteristics of adolescence and young adulthood may influence the experience of symptoms as well as individuals' consequent efforts to selfmanage those symptoms and articulate these efforts. This underscores the well-recognized need for developmentally appropriate care and communication, not only in general, but specifically with the goal of understanding their symptom experience and self-management efforts.

Adolescents and young adults are not a homogeneous developmental group, and adolescents may differ from young adults in ways that impact their symptom self-management. Young adults named more symptom self-management strategies, while adolescents had more missing data. Young adults may possibly engage more in symptom self-management due to greater cognitive capacity or social expectation for them to do so. Alternatively, young adults may possess a greater ability to recognize that they are engaging in symptom selfmanagement and/or to express the same. They also may be more inclined to share their experiences, including symptom experiences, with others.

Evidence-based guidelines for managing individual symptoms are available for some but not many cancer-related symptoms. Despite the lack of evidence-based guidelines for a number of symptoms, recommendations exist for managing most symptoms. Many of these guidelines and recommendations are publicly available on websites such as the National Cancer Institute [25-27], CureSearch for Children's Cancer [28-30], the Oncology Nursing Society [31], and the Pediatric Oncology Group of Ontario [32]. Whether selfmanagement strategies from these guidelines or 
Table 3 Self-management strategies reported by participants for each symptom

\begin{tabular}{|c|c|c|c|c|c|c|}
\hline \multirow[t]{2}{*}{ Symptom } & \multirow{2}{*}{$\begin{array}{l}\text { Number reporting } \\
\text { symptom }(\%)\end{array}$} & \multicolumn{3}{|l|}{ Themes } & \multirow{2}{*}{$\begin{array}{l}\text { Reported } \\
\text { "nothing" }\end{array}$} & \multirow{2}{*}{$\begin{array}{l}\text { Reported "do } \\
\text { not know" }\end{array}$} \\
\hline & & $\begin{array}{l}\text { Things I take... } \\
\text { or not }\end{array}$ & Physical care things I do & Psychosocial care things I do & & \\
\hline & & \multicolumn{5}{|c|}{ Participants reporting subthemes for each symptom } \\
\hline \multirow[t]{7}{*}{ Nausea } & $47(65.3)$ & $\begin{array}{l}\text { Medications } \\
\quad(42)\end{array}$ & Eating strategies (8) & Psychosocial/relational (1) & 0 & 0 \\
\hline & & $\begin{array}{l}\text { Medication } \\
\text { management } \\
\text { (1) }\end{array}$ & $\begin{array}{l}\text { Complementary/integrative } \\
\text { medicine strategies (6) }\end{array}$ & $\begin{array}{l}\text { Cognitive/emotional/spiritual } \\
\text { strategies (1) }\end{array}$ & & \\
\hline & & $\begin{array}{l}\text { Substance use } \\
\text { (2) }\end{array}$ & & $\begin{array}{l}\text { Living day-to-day } \\
\text { with cancer (1) }\end{array}$ & & \\
\hline & & & Drinking and hydration (4) & & & \\
\hline & & & Sleep/rest strategies (4) & & & \\
\hline & & & $\begin{array}{l}\text { Appearance/personal care } \\
\text { strategies (2) }\end{array}$ & & & \\
\hline & & & Supportive care resources (1) & & & \\
\hline \multirow[t]{4}{*}{ Feeling drowsy } & $40(55.6)$ & $\begin{array}{l}\text { Medication } \\
\text { management } \\
(5)\end{array}$ & Sleep/rest strategies (24) & $\begin{array}{l}\text { Psychosocial/relational } \\
\text { strategies (2) }\end{array}$ & 3 & 1 \\
\hline & & $\begin{array}{l}\text { Substance use } \\
\text { (3) }\end{array}$ & $\begin{array}{l}\text { Physical activity/physical } \\
\text { movement/exercise (4) }\end{array}$ & $\begin{array}{l}\text { Living day-to-day } \\
\text { with cancer }(3)\end{array}$ & & \\
\hline & & Medications (1) & Eating strategies (2) & $\begin{array}{l}\text { Cognitive/emotional/spiritual } \\
\text { strategies (1) }\end{array}$ & & \\
\hline & & $\begin{array}{l}\text { Medical } \\
\text { intervention } \\
\text { (1) }\end{array}$ & $\begin{array}{l}\text { Managing the physical } \\
\text { environment (1) }\end{array}$ & Waiting strategies (1) & & \\
\hline \multirow[t]{4}{*}{ Lack of appetite } & $40(55.6)$ & Medications (9) & Eating strategies (19) & $\begin{array}{l}\text { Living day-to-day } \\
\text { with cancer }(2)\end{array}$ & 4 & 1 \\
\hline & & $\begin{array}{l}\text { Substance use } \\
\text { (3) }\end{array}$ & $\begin{array}{l}\text { Drinking/hydration strategies } \\
\text { (2) }\end{array}$ & Waiting strategies (3) & & \\
\hline & & $\begin{array}{l}\text { Medical } \\
\text { intervention } \\
\text { (2) }\end{array}$ & $\begin{array}{l}\text { Physical activity/physical } \\
\text { movement/exercise (1) }\end{array}$ & $\begin{array}{l}\text { Psychosocial/relational } \\
\text { strategies (1) }\end{array}$ & & \\
\hline & & $\begin{array}{l}\text { Medication } \\
\text { management } \\
\text { (1) }\end{array}$ & Sleep/rest strategies (1) & $\begin{array}{l}\text { Cognitive/emotional/spiritual } \\
\text { strategies (1) }\end{array}$ & & \\
\hline \multirow[t]{4}{*}{ Lack of energy } & $40(55.6)$ & $\begin{array}{l}\text { Medication } \\
\text { management } \\
(6)\end{array}$ & Sleep/rest strategies (23) & $\begin{array}{l}\text { Cognitive/emotional/spiritual } \\
\text { strategies (2) }\end{array}$ & 3 & 0 \\
\hline & & & $\begin{array}{l}\text { Physical activity/physical } \\
\text { movement/exercise (12) }\end{array}$ & $\begin{array}{l}\text { Living day-to-day } \\
\text { with cancer }(2)\end{array}$ & & \\
\hline & & & $\begin{array}{l}\text { Drinking/hydration strategies } \\
\text { (5) }\end{array}$ & $\begin{array}{l}\text { Psychosocial/relational } \\
\text { strategies (1) }\end{array}$ & & \\
\hline & & & Eating strategies (4) & & & \\
\hline \multirow[t]{2}{*}{ Hair loss } & $34(47.2)$ & $\begin{array}{l}\text { Medication } \\
\text { management } \\
(6)\end{array}$ & Appearance/personal care (8) & $\begin{array}{l}\text { Living day-to-day } \\
\text { with cancer (2) }\end{array}$ & 9 & 1 \\
\hline & & & & Waiting (1) & & \\
\hline \multirow[t]{4}{*}{$\begin{array}{l}\text { Changes in how } \\
\text { food tastes }\end{array}$} & $33(45.8)$ & Medications (2) & Eating strategies (18) & $\begin{array}{l}\text { Psychosocial/relational } \\
\text { strategies (1) }\end{array}$ & 2 & 6 \\
\hline & & $\begin{array}{l}\text { Substance use } \\
\text { (1) }\end{array}$ & Supportive care resources (2) & Waiting strategies (1) & & \\
\hline & & & Drinking and hydration (1) & & & \\
\hline & & & $\begin{array}{l}\text { Complementary/integrative } \\
\text { medicine strategies (1) }\end{array}$ & & & \\
\hline \multirow[t]{2}{*}{$\begin{array}{l}\text { Difficulty } \\
\text { sleeping }\end{array}$} & $32(44.4)$ & $\begin{array}{l}\text { Medications } \\
\text { (13) }\end{array}$ & $\begin{array}{l}\text { Managing the physical } \\
\text { environment (6) }\end{array}$ & $\begin{array}{l}\text { Cognitive/emotional/spiritual } \\
\text { strategies (3) }\end{array}$ & 1 & 3 \\
\hline & & & Sleep/rest strategies (6) & $\begin{array}{l}\text { Psychosocial/relational } \\
\text { strategies (2) }\end{array}$ & & \\
\hline
\end{tabular}


Table 3 (continued)

\begin{tabular}{|c|c|c|c|c|c|c|}
\hline \multirow[t]{2}{*}{ Symptom } & \multirow{2}{*}{$\begin{array}{l}\text { Number reporting } \\
\text { symptom }(\%)\end{array}$} & \multicolumn{3}{|l|}{ Themes } & \multirow{2}{*}{$\begin{array}{l}\text { Reported } \\
\text { "nothing" }\end{array}$} & \multirow{2}{*}{$\begin{array}{l}\text { Reported "do } \\
\text { not know" }\end{array}$} \\
\hline & & $\begin{array}{l}\text { Things I take... } \\
\text { or not }\end{array}$ & Physical care things I do & Psychosocial care things I do & & \\
\hline Dry mouth & $26(36.1)$ & Medications (5) & $\begin{array}{l}\text { Physical activity/physical } \\
\text { movement/exercise (4) } \\
\text { Complementary/integrative } \\
\text { medicine strategies (1) } \\
\text { Drinking and hydration (20) } \\
\text { Supportive care resources (4) } \\
\text { Complementary/integrative } \\
\text { medicine strategies (1) } \\
\text { Eating strategies (1) }\end{array}$ & $\begin{array}{l}\text { Living day-to-day } \\
\text { with cancer (1) } \\
\text { Waiting strategies (1) }\end{array}$ & 0 & 2 \\
\hline Pain & $26(36.1)$ & $\begin{array}{l}\text { Medications } \\
\quad(26) \\
\text { Substance use } \\
\quad(2) \\
\text { Medication } \\
\quad \text { management } \\
\quad(1)\end{array}$ & $\begin{array}{l}\text { Complementary/integrative } \\
\text { medicine strategies (10) } \\
\text { Sleep/rest strategies (4) } \\
\text { Physical activity/physical } \\
\text { movement/exercise (3) } \\
\text { Appearance/personal care } \\
\text { strategies (1) }\end{array}$ & & 0 & 0 \\
\hline Weight loss & $23(31.9)$ & $\begin{array}{l}\text { Medications (5) } \\
\text { Substance use } \\
\text { (1) }\end{array}$ & $\begin{array}{l}\text { Eating strategies (19) } \\
\text { Physical activity/physical } \\
\text { movement/exercise (1) } \\
\text { Drinking/hydration strategies } \\
\text { (1) } \\
\text { Complementary/integrative } \\
\text { medicine strategies (1) }\end{array}$ & $\begin{array}{l}\text { Living day-to-day } \\
\text { with cancer (2) } \\
\text { Waiting strategies (1) }\end{array}$ & 0 & 0 \\
\hline Feeling irritable & $22(30.6)$ & $\begin{array}{l}\text { Medications (2) } \\
\text { Medication } \\
\text { management } \\
\text { (1) } \\
\text { Substance use } \\
\quad \text { (1) }\end{array}$ & $\begin{array}{l}\text { Eating strategies (2) } \\
\text { Complementary/integrative } \\
\text { medicine strategies (1) } \\
\text { Managing the physical } \\
\text { environment (1) } \\
\text { Physical activity/physical } \\
\text { movement/exercise (1) } \\
\text { Supportive care resources (1) }\end{array}$ & $\begin{array}{l}\text { Psychosocial/relational } \\
\text { strategies (11) } \\
\text { Cognitive/emotional/spiritual } \\
\text { strategies (1) }\end{array}$ & 0 & 0 \\
\hline Vomiting & $22(30.6)$ & $\begin{array}{l}\text { Medications } \\
(15) \\
\text { Medication } \\
\text { management } \\
\text { (1) }\end{array}$ & $\begin{array}{l}\text { Sleep/rest strategies (3) } \\
\text { Eating strategies (4) } \\
\text { Complementary/integrative } \\
\text { medicine strategies (3) }\end{array}$ & $\begin{array}{l}\text { Living day-to-day } \\
\text { with cancer }(5)\end{array}$ & 0 & 0 \\
\hline Worrying & $21(29.2)$ & $\begin{array}{l}\text { Medications (2) } \\
\text { Substance use } \\
\text { (1) }\end{array}$ & $\begin{array}{l}\text { Complementary/integrative } \\
\text { medicine strategies (3) } \\
\text { Sleep/rest (1) } \\
\text { Appearance/personal care (1) }\end{array}$ & $\begin{array}{l}\text { Living day-to-day } \\
\text { with cancer (9) } \\
\text { Psychosocial/relational } \\
\text { strategies (9) } \\
\text { Cognitive/emotional/spiritual } \\
\text { strategies (4) } \\
\text { Waiting strategies (1) }\end{array}$ & 0 & 1 \\
\hline Dizziness & $20(27.8)$ & Medications (3) & $\begin{array}{l}\text { Physical activity/physical } \\
\text { movement/exercise (9) } \\
\text { Sleep/rest strategies (7) }\end{array}$ & Waiting (1) & 0 & 1 \\
\hline
\end{tabular}


Table 3 (continued)

\begin{tabular}{|c|c|c|c|c|c|c|}
\hline \multirow[t]{2}{*}{ Symptom } & \multirow{2}{*}{$\begin{array}{l}\text { Number reporting } \\
\text { symptom }(\%)\end{array}$} & \multicolumn{3}{|l|}{ Themes } & \multirow{2}{*}{$\begin{array}{l}\text { Reported } \\
\text { "nothing" }\end{array}$} & \multirow{2}{*}{$\begin{array}{l}\text { Reported "do } \\
\text { not know" }\end{array}$} \\
\hline & & $\begin{array}{l}\text { Things I take... } \\
\text { or not }\end{array}$ & Physical care things I do & Psychosocial care things I do & & \\
\hline & & $\begin{array}{l}\text { Medication } \\
\text { management } \\
\text { (1) } \\
\text { Substance use } \\
\quad(1)\end{array}$ & $\begin{array}{l}\text { Drinking/hydration strategies } \\
\text { (1) } \\
\text { Eating strategies (1) }\end{array}$ & & & \\
\hline $\begin{array}{l}\text { Difficulty } \\
\text { concentrating }\end{array}$ & $18(25.0)$ & $\begin{array}{l}\text { Medication } \\
\text { management } \\
\text { (1) }\end{array}$ & $\begin{array}{l}\text { Physical activity/physical } \\
\text { movement/exercise (2) } \\
\text { Sleep/rest strategies (1) }\end{array}$ & $\begin{array}{l}\text { Cognitive/emotional/spiritual } \\
\text { (5) } \\
\text { Waiting strategies ( } 3 \text { ) } \\
\text { Living day-to-day with cancer } \\
\quad \text { (1) } \\
\text { Psychosocial/relational (1) }\end{array}$ & 1 & 1 \\
\hline $\begin{array}{l}\text { Do not look like } \\
\text { myself }\end{array}$ & $18(25.0)$ & $\begin{array}{l}\text { Medication } \\
\text { management } \\
(2) \\
\text { Medications (1) }\end{array}$ & $\begin{array}{l}\text { Physical activity/physical } \\
\text { movement/exercise (2) } \\
\text { Drinking/hydration strategies } \\
\quad(1) \\
\text { Eating strategies (1) } \\
\text { Sleep/rest strategies (1) }\end{array}$ & $\begin{array}{l}\text { Living day-to-day } \\
\text { with cancer (1) } \\
\text { Waiting (1) }\end{array}$ & 3 & 1 \\
\hline Sweating & $18(25.0)$ & - & $\begin{array}{l}\text { Managing the physical } \\
\text { environment (14) } \\
\text { Complementary/integrative } \\
\text { medicine strategies (2) } \\
\text { Sleep/rest strategies (1) }\end{array}$ & $\begin{array}{l}\text { Living day-to-day } \\
\text { with cancer (1) }\end{array}$ & 2 & 4 \\
\hline Feeling nervous & $16(22.2)$ & Medications (2) & $\begin{array}{l}\text { Sleep/rest strategies (2) } \\
\text { Complementary/integrative } \\
\text { medicine strategies (1) } \\
\text { Appearance/personal care (1) }\end{array}$ & $\begin{array}{l}\text { Cognitive/emotional/spiritual } \\
\text { strategies (7) } \\
\text { Living day-to-day } \\
\text { with cancer (4) } \\
\text { Psychosocial/relational } \\
\text { strategies (4) } \\
\text { Waiting strategies (1) }\end{array}$ & 0 & 0 \\
\hline Constipation & $15(20.8)$ & $\begin{array}{l}\text { Medications } \\
\quad(14) \\
\text { Medication } \\
\text { management } \\
\text { (1) }\end{array}$ & $\begin{array}{l}\text { Eating strategies (3) } \\
\text { Drinking and hydration (3) }\end{array}$ & $\begin{array}{l}\text { Living day-to-day } \\
\text { with cancer }(1)\end{array}$ & 0 & 0 \\
\hline \multirow[t]{2}{*}{ Feeling sad } & $14(19.4)$ & $\begin{array}{l}\text { Medication } \\
\text { management } \\
\text { (1) }\end{array}$ & $\begin{array}{l}\text { Physical activity/physical } \\
\text { movement/exercise (1) }\end{array}$ & Psychosocial/relational (10) & 1 & 1 \\
\hline & & & & $\begin{array}{l}\text { Living day-to-day } \\
\text { with cancer (5) } \\
\text { Cognitive/emotional/spiritual } \\
\text { strategies (4) } \\
\text { Waiting strategies (1) }\end{array}$ & & \\
\hline Skin changes & $14(19.4)$ & $\begin{array}{l}\text { Medication } \\
\text { management } \\
(2) \\
\text { Medications (1) }\end{array}$ & $\begin{array}{l}\text { Physical activity/physical } \\
\text { movement/exercise (1) } \\
\text { Complementary/integrative } \\
\text { medicine strategies (1) }\end{array}$ & Waiting strategies (1) & 0 & 3 \\
\hline Cough & $11(15.3)$ & Medications (7) & & Waiting (1) & 1 & 0 \\
\hline
\end{tabular}


Table 3 (continued)

\begin{tabular}{|c|c|c|c|c|c|c|}
\hline \multirow[t]{2}{*}{ Symptom } & \multirow{2}{*}{$\begin{array}{l}\text { Number reporting } \\
\text { symptom }(\%)\end{array}$} & \multicolumn{3}{|l|}{ Themes } & \multirow{2}{*}{$\begin{array}{l}\text { Reported } \\
\text { "nothing" }\end{array}$} & \multirow{2}{*}{$\begin{array}{l}\text { Reported "do } \\
\text { not know" }\end{array}$} \\
\hline & & $\begin{array}{l}\text { Things I take... } \\
\text { or not }\end{array}$ & Physical care things I do & Psychosocial care things I do & & \\
\hline $\begin{array}{l}\text { Tingling in } \\
\text { hands and } \\
\text { feet }\end{array}$ & $9(12.5)$ & & $\begin{array}{l}\text { Complementary/integrative } \\
\text { medicine strategies (2) } \\
\text { Drinking/hydration } \\
\text { strategies (1) } \\
\text { Complementary/integrative } \\
\text { medicine strategies (3) } \\
\\
\text { Managing physical } \\
\text { environment (1) } \\
\text { Physical activity/physical } \\
\text { movement/exercise (3) } \\
\text { Sleep/rest strategies (1) }\end{array}$ & & 1 & 1 \\
\hline Itching & $8(11.1)$ & Medications (4) & Supportive care resources (3) & & 0 & 1 \\
\hline $\begin{array}{l}\text { Swelling in } \\
\text { arms and legs }\end{array}$ & $7(9.7)$ & Medications (1) & $\begin{array}{l}\text { Physical activity/physical } \\
\text { movement/exercise (2) }\end{array}$ & $\begin{array}{l}\text { Living day-to-day } \\
\text { with cancer (1) }\end{array}$ & 2 & 1 \\
\hline Diarrhea & $5(6.9)$ & $\begin{array}{l}\text { Medication } \\
\text { management } \\
(1) \\
\text { Medications (3) }\end{array}$ & $\begin{array}{l}\text { Eating strategies (2) } \\
\text { Drinking/hydration strategies } \\
\quad(1) \\
\text { Sleep/rest strategies (1) }\end{array}$ & Waiting strategies (1) & 1 & 0 \\
\hline $\begin{array}{l}\text { Difficulty } \\
\text { swallowing }\end{array}$ & $4(5.6)$ & Medications (2) & $\begin{array}{l}\text { Drinking/hydration strategies } \\
\text { (1) } \\
\text { Supportive care resources (1) }\end{array}$ & & 1 & 0 \\
\hline $\begin{array}{l}\text { Shortness of } \\
\text { breath }\end{array}$ & $2(2.8)$ & & $\begin{array}{l}\text { Physical activity/physical } \\
\text { movement/exercise (2) } \\
\text { Complementary/integrative } \\
\text { medicine strategies }(1)\end{array}$ & & 0 & 0 \\
\hline $\begin{array}{l}\text { Problems with } \\
\text { urination }\end{array}$ & $1(1.4)$ & - & - & - & - & - \\
\hline
\end{tabular}

recommendations are discussed with AYAs and how many or which ones they decide to try is unclear.

Although we did not ask participants for the complete list of strategies they used or had tried for each symptom, we did ask, from their perspective, what makes the symptom better. We do not know if they had tried other recommended strategies and found them ineffective or if they were unaware of other strategies. While technology-based resources, such as the C-SCAT, may facilitate patients' reporting of selfmanagement strategies, intentional efforts to ask about symptom self-management strategies can inform providers about strategies AYAs are using or have tried. Providers can direct their patients to available evidence-based symptom selfmanagement strategies, particularly for priority symptoms.

Future research should explore medication management by AYAs with cancer to provide insight into how knowledgeable they are about taking the right medication for the right symptom, at the right dose and frequency, and management of medication side effects. Existing evidence shows that AYAs with cancer have insufficient sleep and physical activity [33-35]. Self-management related to promoting sleep and physical activity is an important area for intervention development. Diet has implications for growth and development as well as future risks for cardiovascular disease and diabetes. Exploring the nutritional choices AYAs make during cancer treatment is another research opportunity. Development of useful psychosocial self-management interventions for this age group is both necessary and challenging. Exploring the meaning of "I do not know" and "nothing" to ensure we have adequate understanding of these terms within the context of AYA symptom self-management is critical to success.

\section{Limitations}

Limitations of this study include its cross-sectional design with data collection at a single point in time and a heterogeneous sample with regards to diagnosis. Many participants were receiving anti-emetic medications with sedating side 
effects, which may have limited their ability to provide extensive responses. The 24-h recall period limited the ability to gain perspective on self-management strategies outside of the healthcare setting or on a day-to-day basis. Participants were not asked to elaborate on their responses or comment on the degree of perceived effectiveness of their named strategies. Reasons for missing data were also not explored. Whether missing responses reflect response fatigue or the lack of a specific symptom self-management strategy is unknown. Because the study sample was largely White/non-Hispanic, the opportunity to explore self-management strategies among racial/ethnic minority groups was limited.

\section{Conclusion}

Just as cancer symptom experiences are complex and personal, so are symptom self-management strategies. This study described AYAs' symptom self-management strategies from their perspectives. The study provides a foundation for future research to empower young people as advocates for their symptom management needs and to support healthcare providers to engage in symptom self-management discussions and to offer strategy options.

Acknowledgements This work was supported by St. Baldrick's Foundation (Supportive Care Grant, 2011-13), University of Utah College of Nursing, Seattle Children's Guild Association Teen Cancer Grant, Hyundai Hope on Wheels, University of Virginia School of Nursing, and the National Institute of Nursing Research, NIH (P30 NR011403 Center of Excellence for Biobehavioral Approaches to Symptom Management). The authors wish to acknowledgement Pamela S. Hinds, PhD, RN, FAAN, and Nancy F. Woods, PhD, RN, FAAN, for their mentorship during this study; the Intermountain Healthcare Homer Warner Center for Informatics Research for programming the C-SCAT; and the research assistants at each site. Finally, we wish to acknowledge our AYA participants for sharing their symptom experiences and symptom self-management strategies through the C-SCAT.

\section{References}

1. Bleyer A (2007) Young adult oncology. The patients and their survival challenges. Cancer 57:242-255. doi:10.3322/canjclin.57.4.242

2. Conger JJ, Galambos NL. (1997) Adolescence and youth: psychological development in a changing world ( $5^{\text {th }}$ ed.). Longman publishing group, New York

3. Nass SL, Beaupin LK, Demark-Wahnefried W et al (2015) Identifying and addressing the needs of adolescents and young adults with cancer: Summary of an Institute of Medicine workshop. Oncologist 20:186-195. doi:10.1634/theoncologist.2014-0265

4. DeRouen M, Smith AW, Tao L et al (2015) Cancer-related information needs and cancer's impact on control over life influence health-related quality of life among adolescents and young adults with cancer. Psychooncology 24:1104-1115. doi:10.1002/pon. 3730

5. Smith AW, Belizzi KM, Keegan TH et al (2013) Health-related quality of life of adolescent and young adult patients with cancer in the United States: the adolescent and young adult health outcomes and patient experience study. J Clin Oncol 31:2136-2145. doi:10.1200/JCO.2012.47.47.3173

6. Ameringer S, Erickson JM, Macpherson CF, Stegenga K, Linder LA (2015) Symptoms and symptom clusters identified by adolescents and young adults with cancer using a symptom heuristics app. Res Nurs Health 38:436-448. doi:10.1002/nur.21697

7. Ryan P, Sawin K (2009) The individual and family selfmanagement theory: background and perspectives on context, process, and outcomes. Nurs Outlook 57:217-225. doi:10.1016/j. outlook.2008.10.004

8. Moody L, Turner A, Osmond J et al (2015) Web-based self-management for young cancer survivors: consideration of user requirements and barriers to implementation. J Cancer Surviv 9:188-200

9. Palmer S, Patterson P, Thompson K (2014) A national approach to improving adolescent and young adult (AYA) oncology psychosocial care: the development of AYA-specific psychosocial assessment and care tools. Palliat Support Care 12:183-188

10. Morgan S, Davies S, Palmer S, Plaster M (2010) Sex, drugs, and rock ' $n$ ' roll: caring for adolescents and young adults with cancer. J Clin Oncol 28:4825-4830

11. Trevino KM, Fasciano K, Prigerson HG (2013) Patient-oncologist alliance, psychosocial well-being, and treatment adherence among young adults with advanced cancer. J Clin Oncol 31:1683-1689

12. Jedeloo S, van Staa A, Latour JM, van Exel NJ (2010) Preferences for health care and self-management among Dutch adolescents with chronic conditions: a Q-methodological investigation. Int J Nurs Stud 47:593-603

13. Stinson JN, Sung L, Gupta A et al (2012) Disease self-management needs of adolescents with cancer: perspectives of adolescents with cancer and their parents and healthcare providers. J Cancer Surviv 6:278-286

14. Kwak M, Zebrack BJ, Meeske KA et al (2013) Trajectories of psychological distress in adolescent and young adult patients with cancer: a 1-year longitudinal study. J Clin Oncol 31:2160-2166

15. Zebrack BJ, Block R, Hayes-Lattin B et al (2013) Psychosocial service use and unmet need among recently diagnosed adolescent and young adult cancer patients. Cancer 119:201-214

16. Syed IA, Nathan PC, Barr R et al (2016) Examining factors associated with self-management skills in teenage survivors of cancer. J Cancer Surviv 10:686-691. doi:10.1007/s11764-016-0514-y

17. Stinson JN, Jibb LA, Nguyen C et al (2013) Development and testing of a multidimensional iPhone pain assessment application for adolescents with cancer. J Med Internet Res 15:e51. doi:10. 2196/jmir.2350

18. Rodgers CC, Krance R, Street RL Jr, Hockenberry MJ (2013) Feasibility of a symptom management intervention for adolescents recovering from a hematopoietic stem cell transplant. Cancer Nurs 36:394-399. doi:10.1097/NCC.0b013e31829629b5

19. Macpherson CF, Linder LA, Ameringer S et al (2014) Feasibility and acceptability of an iPad application to explore symptom clusters in adolescents and young adults with cancer. Pediatr Blood Cancer 61:1996-2003. doi:10.1002/pbc.25152

20. Collins JJ, Byrnes ME, Dunkel IJ et al (2000) The measurement of symptoms in children with cancer. J Pain Symptom Manag 19:363377

21. Amazon Web Services. Amazon $\mathrm{S}^{3}$. https://aws.amazon.com/s3/. Accessed 5 December 2016

22. Elo S, Kyngas H (2008) The qualitative content analysis process. J Adv Nurs 62:107-115. doi:10.1111/j.1365-2648.2007.04569.x

23. Hsieh HF, Shannon SE (2005) Three approaches to qualitative content analysis. Qual Health Res 15:1277-1288. doi:10.1177/ 1049732305276687

24. Ramphal R, Aubin S, Czaykowski P et al (2016) Adolescent and young adult cancer: principles of care. Curr Onc 23:204-209. doi: $10.3747 / \mathrm{co} .23 .3013$ 
25. National Cancer Institute. Side effects (2015) https:/www.cancer.gov/ about-cancer/treatment/side-effects. Accessed 27 December 2016

26. National Cancer Institute. Nausea and vomiting (PDQ $\left.{ }^{\circledR}\right)-$ Health Professional Version (2016) https://www.cancer.gov/about-cancer/ treatment/side-effects/nausea/nausea-hp-pdq\#section/all. Accessed 27 December 2016

27. National Cancer Institute. Nutrition in cancer care (PDQ®)-Health Professional Version (2016) https://www.cancer.gov/about-cancer/ treatment/side-effects/appetite-loss/nutrition-hp-pdq\#section/all. Accessed 27 December 2016

28. CureSearch for Children's Cancer. Treatment side effects. http:// curesearch.org/Treatment-Side-Effects. Accessed 27 December 2016

29. CureSearch for Children's Cancer. nausea and vomiting. http:// curesearch.org/Nausea-and-Vomiting. Accessed 27 December 2016

30. CureSearch for Children's Cancer. Appetite problems. http:// curesearch.org/Appetite-Problems. Accessed 27 December 2016

31. Oncology Nursing Society. Putting evidence into practice (PEP). https://www.ons.org/practice-resources/pep. Accessed 2 March 2017
32. Pediatric Oncology Group of Ontario (2013) Guideline for the prevention of acute nausea and vomiting due to antineoplastic medication in pediatric cancer patients http://www.pogo.ca/ media/File/ guidelines/POGO_Acute_AINV_Full_Guideline_Feb_28_2013. pdf. Accessed 27 December 2016

33. Murnane A, Gough K, Thompson K, Holland L, Conyers R (2015) Adolescents and young adult cancer survivors: exercise habits, quality of life and physical activity preferences. Support Care Cancer 23:501-510. doi:10.1007/s00520-014-2446-2

34. Orsey AD, Wakefield DB, Cloutier MM (2013) Physical activity (PA) and sleep among children and adolescents with cancer. Ped Blood Cancer 60:1908-1913. doi:10.1002/pbc.24880

35. Palesh O, Peppone L, Innominato PF et al (2012) Prevalence, putative mechanisms, and current management of sleep problems during chemotherapy for cancer. Nature Science Sleep 4:151-162. doi: $10.2147 /$ NSS.S18895 